\title{
Competing Multiple Accountability Mechanisms and Public Administrators' Responses in the Health Sector in Kenya
}

Karumba, Kenneth

University of Nairobi

Received: April 15, 2020 Accepted: May 18, 2020 Online published: June 2, 2020

doi:10.5296/jpag.v10i2.17140～URL: https://doi.org/10.5296/jpag.v10i2.17140

\begin{abstract}
Accountability in public sector is a complex concept. Public administrators are held accountable by multiple mechanisms of accountability. It is unclear in the public health sector in Kenya which of the four mechanisms of hierarchical, professional, legal and political accountability dominates accountability responses of hospital administrators. The objective of this study was to assess which among the competing multiple accountability mechanism is accorded priority in the health sector in Kenya. The study adopted a case study design targeting hospital administrators from 36 public hospitals in 14 Counties in Kenya. The study found out that professional accountability tend to be given precedence over other forms of public accountability in ordinary conditions and hierarchical accountability under crisis situations. The study concluded that hospital administrators are confronted with all the four mechanisms, but their intensity on accountability vary.
\end{abstract}

Keywords: public administrators, accountability, health sector

\section{Introduction}

Accountability is one of the concepts that has evaded a clear definition and has been associated with terms such as "transparency, equity, democracy, efficiency, responsiveness, responsibility and integrity" (Boven, 2007 p. 449). From a Principle-Agent point of view, accountability is a process of defining rules and regulations and the employment of various mechanisms to ensure compliance (principle perspective) and a duty to provide information and to explain and justify administrator's actions (agent perspective).

Throughout the world, the landscape of accountability has been expanding due to the ever increasing democratic space and diverse reforms undertaken by governments and public sector in the past three decades. Accountability has thus been regarded as "the hallmark of modern democratic governance" (McDanel, 2012 p. 116). Separately from accountability 
being a product of government initiative and programme, in the years that followed, citizens too have had a share in expanding public accountability. Citizen have demanded from government's higher productivity without necessarily increased taxation, quality public services comparable or better that the private sector, and increased public and media scrutiny on performance, public spending and decision making. In the recent times, performance competency among public administrators is never enough, behaviours such as fairness, truthfulness and, respect are becoming important in maintaining public trust and confidence. These attributes are becoming key values in public management. While the decade's long trends in public management backed by globalization and devolution (Kettl, 2002) have painted a picture of growing accountability, some studies have argued that the recent trends in the public sectors are reversing gains in accountability. Frederickson \& Smith (2003) and Aberbach and Rockman (2000) have noted that widespread practice of contracting out and systems of proxy management as a public service delivery strategy are weakening accountability.

\section{Background}

Public administrators throughout the world are expected to be accountable in their discharge of official duties. It is important that public administrators are held accountable since they are contracted to perform vital and essential functions that are relied on by both the citizenry and the state. The public depend on effective and efficient execution of administrative duties that constitute service delivery. These services include social services such as health, education, justice, security and utility (electricity, water and waste management). On the other hand, the state depends on provision of aforementioned services and many others to gain legitimacy (Mandefro, Noor \& Stel, 2012).

A number of mechanisms have been established to guarantee public accountability in the public service. These accountability mechanisms imposed by principles include hierarchical, professional, legal and political accountability (Dowdle, 2006; Jos and Tomkins, 2004; Kim and Lee, 2010; Romzek \& Dubnick, 1987; Romzek \& Ingraham, 2000; Salminen and Lehto, 2012).

Public accountability has been studied globally in different jurisdictions from multidimensional approaches (Blind, 2011). These approaches include, what accountability consists of (prescriptive), to whom accountability is rendered (descriptive), where and how accountability operates (operational) and when accountability occurred (longitudinal).

This paper approaches public accountability from a descriptive perspective focusing on whom the hospital administrators in the health sector in Kenya are accountable during normal conditions and crisis situations within the context of multiple accountability mechanisms. Various studies have explored and suggested the existence of competing multiple accountability mechanisms that often creates "cross-pressure" in public administration. The central theme of these perspectives is the potential negative consequences associated with competing accountability demands in the public sector (Dubnick \&Yang, 2011; Kim \& Lee, 2009). 
Romzek and Dubnick (1987) assessed institutional factors that played part in the Space Shuttle 'Challenger' accident from multiple and competing accountability mechanisms. In a related study, Romzek and Ingraham (2000) analysed gap between managerial reforms in the public service and the reality of accountability expectation and the cross pressures individuals face from multiple accountability mechanisms. This later study was conducted in the US military centering on another disaster and highlighted factors associated with reverting to hierarchical accountability during crisis as opposed to professional accountability in normal situations. These two studies focused on the agencies in relation to public accountability, less emphasis was placed on individual public administrator's behaviour within the complicated web of multiple accountability.

However, Boven and Schillemans (2011) did not view the concept of multiple accountability mechanisms as necessarily complex and with negative outcomes. In their assessment of overload and redundancy effects of multiple accountability in the public sector in the Netherlands using the principal-agent theory, the authors highlighted some positive outcomes of the effects of multiple accountability. They suggested that the positives effect of multiple accountability mechanisms include increased availability of information and an opportunity to entrench legitimate values embodied in public policies. Despite this positive angle, Boven and Schillemans (2011) still identified negative effects multiple accountability to include opportunity cost and blame game.

In Kenya, approaches to public accountability have been longitudinal consisting of assessment of accountability from the colonial period (Ndege, 2009) to post-colonial period (Odhiambo-Mbai, 2003). The other approach is prescriptive focusing on accountability as a desired quality in the context of state of declining standards of accountability due to weak, insufficient or poorly enforced mechanisms and the struggle to enforce and build stronger institutions of accountability. There has been no attempt to approach public accountability from a competing multiple accountability perspective. Existing literature has assessed how mechanisms of hierarchical accountability (Minja, 2013 and Nyamu, 1975), professional accountability (Odhiambo-Mbai, 2003 and Kimiru, 2014), legal accountability (Sihanya, 2012; Gicheru, 2007 and Kameri-Mbote \& Aketch, 2011) and political accountability (Butler, 2010 and Tettey, 2006) have operated in silos to ensure accountability in Kenya's public service. The main theme of accountability studies in Kenya has been on genesis and history of accountability mechanisms (Odhiambo-Mbai and Wanyande, 2001) accountability deficits (Odhiambo-Mbai, 2003) and on financial accountability (Minja, 2003). The later noted that accountability in the public sector in Kenya focuses on "balancing the books as opposed to demonstrating accountability to citizens" (Minja, 2003 p. 61).

In addition, accountability studies in the health sector are few and have focused on financial (Brinkerhoff, 2003), the quality of health service delivery (Cornwall, Lucas, Pasteur, 2000). In Kenya, health specific studies have focused on accountability in primary care (Atela, 2013), loses of funds (Transparency International, 2006), corruption (Kenya AntiCorruption Commission, 2010), and integration of social accountability in health care delivery (Gachie and Iravo, 2016; Machira, 2015; Friis-Hansen and Ravnkilde, 2013). 


\section{MInstitute Mach $_{\text {Int }}$}

Journal of Public Administration and Governance

ISSN 2161-7104

2020, Vol. 10, No. 2

From the literature on competing multiple accountability mechanisms, public accountability is presented as a complex issue. Much accountability is perceived to be fundamental in pursuit of good governance, however on the flip side a web of accountability relationship presents a unique challenge in the public sector including health sector (Brinkerhoff, 2003, Tello \& Baez-Camargo, 2015). Thus for public administrators, "it remains unclear how to deal with cross pressures of accountability and what to do with the often-conflicting prescriptions all claiming to improve accountability" (Dubnick \& Yang, 2011, p.3).

Under such environment, public administrators tend to give priority to one or two accountability mechanisms over the others mechanisms (Bovens, Goodin \& Schillemans, 2014; Kim 2014 and; Kim and Lee, 2010) leading to a debate on the best way to hold public administrators accountable. This age-long debate has divided scholars since the formative years of the discipline of Public Administration as observed by Denhardt, \& Denhardt (2007). Friedrich (1940) argued that the key to bureaucratic responsibility is professionalism, while Finer (1941) argued that external controls, primarily democratic control are better suited to guarantee accountability. Maass and Radaway (1959) proposed that administrators are responsible for conforming to their coordination activities and agencies' heads priorities, while Dimock and Dimock (1969) argued that accountability is a legal and moral duty.

Thus, given the above differing opinion over the most appropriate or dominant mechanism of accountability within the context multiple accountability framework, it not clear what mechanism public administrators respond to under normal conditions in Kenya's health sector. Additionally, the health sector is riddled with frequent crisis. These crises attract rigorous attention and fervent emotions tend to induce equally intense activities associated with public accountability mechanisms (Kuipers and 't Hart, 2014). Hence, under crisis situations do public administrators in the health sector still respond to the same accountability mechanisms or does a different mechanism come into force?

The public health sector is considered in this study because it's one of the largest public sector in Kenya. The sector is very critical to the lives of ordinary citizen and one of the biggest beneficiaries of national public budgetary allocation. The sector occupies a central role in ensuring quality lives for the citizen, in fighting poverty and in economic empowerment.

\section{Objectives of the Study}

The objective of this study is to explore multiple accountability mechanisms and public administrators' dynamic response under normal and crisis environments in Kenya's the health sector.

\section{Theoretical Framework}

Although there is no perfect model for analysing accountability (Jos and Tompkins, 2004 and Weber, 1999), this study is anchored in the principal-agent theory. Principal-agent theory is a better suited paradigm to analyse public accountability (Gailmard, 2012; Schillemans \& Busuioc, 2014; Waterman \& Meier, 1998). Gailmard (2012) articulated that the "Principal-agent theory has become a widely used paradigm for analysing public 
accountability. This is because it provides a flexible framework for modelling innumerable variations in institutional arrangements, and comparing their potential for inducing desirable behavior by agents" (p. 2).

However, the Principal-Agent theory has been criticized for its silence in the event of introduction of multiple principals with externalities and also in its inability to explain bureaucratic behaviour. Hence, in addition to the principal-agent theory this paper also adopts the Romzek and Dubnick (1987) multiple and competing accountability framework to assess accountability mechanism(s) to strengthen argument on the dynamic nature of accountability under the two conditions of normalcy and during crises in the Kenyan heath sector.

To understand the nature of accountability in the Kenyan health sector, I developed the model below that synthesizes both the principal-agent theory and the Romzek and Dubnick (1987) framework of multiple accountability and the two accountability environment of normalcy and crisis. In the multiple and competing accountability framework in illustration 1 below, public administrators are confronted by four accountability mechanisms that include hierarchical, legal, professional and political accountability.

Hierarchical accountability is administered through a clear chain of command where accountability tools such as performance management are utilized to enforce accountability (Jarvis, 2014). In this study, hierarchical accountability refers to answerability by hospital administrators to tasks associated with priorities of those at the top of a hierarchical structure and the coordination activities of public hospitals.

Legal accountability is fulfilled through implementation of public duties as dictated by regulations, statutes, convections, court rulings, conventions and agreements (Johnston \& Romzek, 1999) in the context of this study, legal accountability represents answerability by hospital administrators to tasks associated with compliance with legal obligations of public hospitals.

Professional accountability is exercised through establishment of codes of conduct and professional bodies to guide ethical behaviour among public administrators (Cendón, 1999). In the context of this study, professional accountability means answerability by hospital administrators on decisions made based on professional judgment, ethics and code of conduct as prescribed by various professional guidelines.

Political accountability constitutes public administrators being subjected to scrutiny by elected leaders, the community, media or the international community over their conduct in public offices and on the quality of services delivered by their institutions (Boven, 2007). In this study political accountability represents answerability of hospital administrators to constituencies outside the hospital and public sector hierarchy. This includes the patients, general public, elected officials, the legislature and special interest groups. 
Illustration 1: multiple and competing accountability framework for this study

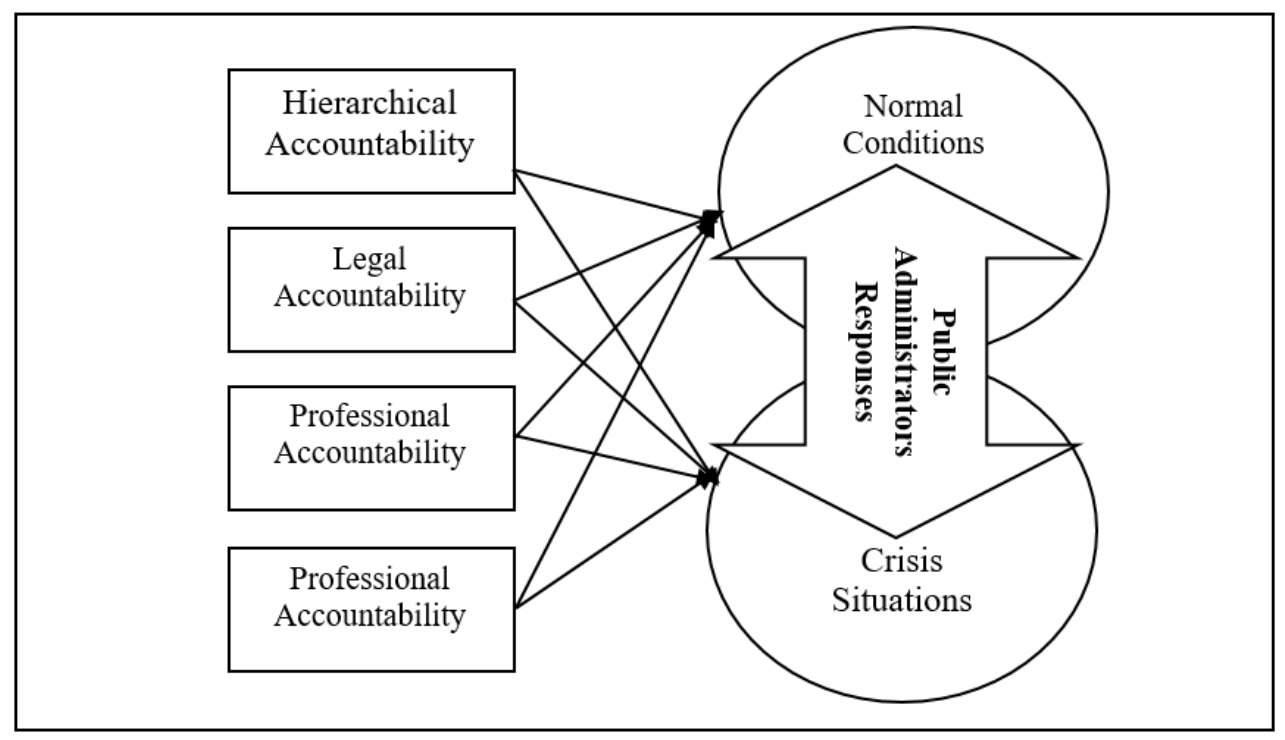

Source, Author

The four mechanisms are imposed by their respective principals to check on public administrator's behaviour. While public administrators are confronted by the four mechanisms, during the normal day to day operations, one mechanism tends to be accorded priority at the expense of the other three; the same applies during crisis situations. Given this scenario this study proposed the following hypotheses:

Hypothesis 1: When public administrators in the Kenya's health sector are simultaneously confronted by multiple mechanisms of hierarchical, legal, professional and political accountability they tend to prioritize one mechanism of accountability over the other mechanisms.

Hypothesis 2: Under normal conditions public administrators in the health sector in Kenya tend to prefer hierarchical accountability over the other mechanisms of accountability.

Hypothesis 3: Under crisis situations public administrators in the health sector in Kenya tend to rely on legal accountability over the other forms of accountability.

\section{Methodology}

\subsection{Research Design}

The study adopted a case study research design to assess the multiple accountability mechanisms and dynamic responses under normal and crisis environments in the Kenya's health sector. Case study research designs are useful for testing whether a specific theory and model actually applies to phenomena in the real world (Bennett, 2004). 


\subsection{Population and Sampling}

This study targeted hospital administrators from 36 public hospitals in 14 Counties in Kenya. Hospital administrators run operational services in government hospitals in the country. Hospital administrators are included in this study because unlike other professionals in the health sector in Kenya, their tasks and answerability allows for testing multiple accountability model consisting of the four mechanisms of hierarchical, professional, legal and political accountability. Thus other cadre and the community are excluded from this study.

The study utilized a non-probability convenience sampling. According to Etikan, Musa, Alkassim (2016), convenience sampling is a nonprobability sampling technique "where members of the target population that meet certain practical criteria, such as easy accessibility, geographical proximity, availability at a given time, or the willingness to participate are included for the purpose of the study" (p.1). Under this technique, hospital administrators from 36 hospitals (one administrator per hospital) in researchers' contact list were included to participate. Yin (1994) observes that parameter establishment and research objective setting are far more important in case study method than a big sample size, and therefore a sample size of 30 or slightly above is appropriate. From a sample size of 36 individuals, a total of 21 individuals responded to the questionnaire, representing a response rate of 63 per cent. A response rate of $60 \%$ and above is considered a very good response rate for mailed questionnaires (Baruch, 1999; Nulty, 2008).

\subsection{Data Collection Procedures}

Data was collected using a self-administered questionnaire. This questionnaire was loaded into Google Form, a web-based platform that allows sharing of questionnaire through a variety of computer and mobile phone communication applications. The web-based questionnaire was emailed to respondents and feedback was received through the same Google Form application platform. Email reminders and phone call follow ups were adopted to increase response rate. This data collection method is effective and efficient because of its potential to reach many and diverse respondents and it involves minimal cost and time.

\subsection{Measurement}

Our main variable is public administrator's response when called to account by multiple principals and the priority accorded to each of the four mechanisms of accountability during normal conditions and in crisis environment. The identification and measure of importance of types of accountability was facilitated by the development of a list of activities that consist of responses to all the four mechanisms of accountability. The survey measurements were developed based on an index by Kim and Lee (2010) and from the literature review. The index was customized to measure public accountability in the Kenyan context through a desk review of existing documents on accountability. To establish which among the four multiple competing accountability mechanisms is accorded priority by administrators under normal conditions in the health sector and why, frequency of responses from each accountability type were computed and compared using mean. A Likert scale responses represented by "never"(1), "rarely"(2), "sometimes" (3), "rather often" (4) and finally "all the time"(5). Thus 
the stronger the mean, the stronger the response to the accountability is.

To determine which among the four multiple competing accountability mechanisms is accorded priority in instances of crisis in the health sector, the study developed a list of a case scenario of possible crisis situations that may arise in a hospital setting and suggested a list of possible responses assigned to a specific accountability type.

\subsection{Data Analysis}

Responses were computed and frequency compared using percentages. Quantitative data analysis from the survey was first analysed using Google Forms application to obtain frequencies. This data was also loaded on SPSS version 20 to run further frequencies and also to obtain and view results through tables. Interpretation of results was guided by the research questions. Data was validated for quality through consistency checks in which data was checked for its consistency with corresponding field. Additionally through cross-system consistency checks, data in the Google Form platform and SPSS was cross checked to ensure consistency.

\section{Results}

\subsection{Background of the Respondents}

The professional background of the respondents is given in table 1 below:

Table 1. Professional Background of the respondents

\begin{tabular}{|l|l|}
\hline Profession & Percentage (\%) \\
\hline Medicine & 25 \\
\hline Social Sciences & 53 \\
\hline Business and Accounting & 22 \\
\hline Total & 100 \\
\hline
\end{tabular}

Majority of the respondents (53\%) professional background is in social sciences followed by those with medical background (25\%) and lastly those with business and accounting qualifications $(22 \%)$.

\subsection{Competing Accountability Mechanisms Under Normal Situation in the Health Sector}

This paper sought to find out which among the four accountability mechanisms is frequently responded to by public administrators in the health sector in Kenya under normal conditions.

\subsubsection{Hierarchical Accountability}

Hierarchical accountability was assessed through a list of tasks associated with this mechanism of accountability as listed in table 2 below. The table presents frequency of undertaking of tasks responsible for hierarchical accountability performed by hospital administrators. 
Table 2. Responses for hierarchical accountability in normal conditions

\begin{tabular}{|c|c|c|c|c|}
\hline Code & Responsibility & $\mathrm{N}$ & Mean & $\begin{array}{l}\text { Std. } \\
\text { Deviation }\end{array}$ \\
\hline A1: & $\begin{array}{l}\text { Duty to obedience and loyalty towards } \\
\text { superior's }\end{array}$ & 21 & 4.40 & .828 \\
\hline A2: & $\begin{array}{l}\text { Increasing work productivity and observing } \\
\text { performance targets }\end{array}$ & 21 & 4.47 & .640 \\
\hline A3: & $\begin{array}{l}\text { Compliance with administrative rules and } \\
\text { procedures }\end{array}$ & 21 & 4.60 & .507 \\
\hline A4: & Financial and expenditure control & 21 & 4.20 & 676 \\
\hline A5: & $\begin{array}{l}\text { Having in mind administrative aspects that } \\
\text { might bring audit queries }\end{array}$ & 21 & 4.40 & .828 \\
\hline A6: & $\begin{array}{l}\text { compliance with hospital strategic planning, } \\
\text { management \& governance }\end{array}$ & 21 & 4.07 & .799 \\
\hline A7: & Implementing decisions of the hospital board & 21 & 4.20 & .676 \\
\hline
\end{tabular}

Compliance with administrative rules and procedures was the most frequently observed hierarchical accountability activity ( $\overline{\mathrm{x}}=4.60)$ followed by increasing work productivity and observing performance targets ( $\bar{x}=4.47$ ). Duty to obedience and loyalty towards superior's and having in mind administrative aspects that might bring audit queries tied at third with $(\bar{x}=4.20)$. Financial and expenditure control and implementing decisions of the Hospital Board came fourthly at $(\overline{\mathrm{x}}=4.20)$. Compliance with hospital strategic planning, management $\&$ governance came third $(\bar{x}=4.07)$.

\subsubsection{Legal Accountability}

Similarly for legal accountability, a list of duties associated with legal accountability was generated as presented in table 3 below. Majority of respondents $(\bar{x}=4.73)$ were more concerned with compliance with Public Procurement and Disposal and Public Financial Management Acts followed by abiding by the Constitution $(\bar{x}=4.47)$, then followed by observing recommendation from commissions including the Ethics and Anti-Corruption Commission (EACC), Commission for Administrative Justice (CAJ), the Kenya National Commission of Human Rights (KNCHR) ( $\bar{x}=4.33)$. This was followed by contract management and minding about legality of administrative decision ( $\bar{x}=4.20)$ with answerability to courts being the least performed task $(\overline{\mathrm{x}}=3.36)$. 
Table 3. Responses for legal accountability in normal conditions

\begin{tabular}{|llccc|}
\hline Code & Responsibility & N & Mean & $\begin{array}{c}\text { Std. } \\
\text { Deviation }\end{array}$ \\
& & & & .516 \\
A7: & Duty to abide by the Constitution & 21 & 4.47 & .775 \\
A8: & Maintaining and servicing annual contract with suppliers & 21 & 4.20 & .7 \\
& and other agencies & 21 & 3.64 & .929 \\
A 9: & Answerability to court processes & 21 & 4.20 & .862 \\
A10: & Legality of administrative decisions & 21 & 4.33 & .816 \\
A11: & Entrenching recommendations/ guidelines from & & \\
& Commission such as EACC, Ombudsman, Human rights & & .458 \\
A12: & Compliance with Public Procurement and Disposal and & 21 & 4.73 & .458 \\
& Public Financial Management Acts & & & \\
\hline
\end{tabular}

\subsubsection{Professional Accountability}

Professional accountability was measured through a list of duties associated with this mechanism as shown in table 4 below. Fairness of administrative decision, compliance with code of conduct and duty to neutrality, impartiality and integrity scored highly $(\bar{x}=4.67)$. This was followed by compliance with professional standards $(\overline{\mathrm{x}}=4.53)$, then dedication to the mission of the Ministry of Health and duty to use appropriately public resources $(\bar{x}=4.47)$. Consideration of peer's contribution/criticism $(\bar{x}=4.27)$ preceded duty to discretion $(\bar{x}=4.27)$. The least implemented activity was achieving professional credentials $(\overline{\mathrm{x}}=4.07)$.

Table 4. Responses for professional accountability in normal conditions

\begin{tabular}{|c|c|c|c|c|}
\hline Code & Responsibility & $\mathrm{N}$ & Mean & $\begin{array}{c}\text { Std. } \\
\text { Deviation }\end{array}$ \\
\hline A13: & $\begin{array}{l}\text { Compliance with professional norms } \\
\text { practices and set standards }\end{array}$ & 21 & 4.47 & .743 \\
\hline A14: & $\begin{array}{l}\text { Ensuring administrative decisions are fair } \\
\text { and reasonable }\end{array}$ & 21 & 4.67 & .488 \\
\hline A15: & $\begin{array}{l}\text { Compliance with Public Service Code of } \\
\text { Conduct and provisions of Public Officers } \\
\text { Ethics Act }\end{array}$ & 21 & 4.53 & .743 \\
\hline A16: & Duty to neutrality, impartiality and integrity & 21 & 4.67 & .488 \\
\hline A17: & $\begin{array}{l}\text { Duty to discretion (autonomy to carry out } \\
\text { your duties as a public administrator) }\end{array}$ & 21 & 4.20 & .775 \\
\hline A 18: & Duty to use appropriately public resources & 21 & 4.47 & .640 \\
\hline A19: & $\begin{array}{l}\text { Consideration of peer's contribution/ } \\
\text { criticism }\end{array}$ & 21 & 4.27 & .799 \\
\hline A20: & $\begin{array}{l}\text { Dedication to the mission of the } \\
\text { Ministry/Hospital }\end{array}$ & 21 & 4.47 & .743 \\
\hline A21: & $\begin{array}{l}\text { Achieving professional credentials } \\
\text { (licenses, certification \& CPDs) }\end{array}$ & 21 & 4.07 & 1.100 \\
\hline
\end{tabular}




\subsubsection{Political Accountability}

Political accountability was assessed through a list of duties associated with this mechanism as shown table 5 below. The highest ranking political accountability activity was implementing collective will of community members in relation to health service delivery $(\bar{x}=4.47)$ followed with maintaining good relation with media and the public $(\bar{x}=4.29)$. Working with other state agencies in improving health services $(\overline{\mathrm{x}}=4.20)$ preceded achieving performance based on the satisfaction of patients and community $(\overline{\mathrm{x}}=4.13)$.

Table 5. Responses to Political Accountability in normal conditions

\begin{tabular}{|c|c|c|c|c|c|}
\hline Code & Responsibility & $\mathbf{N}$ & & Mean & $\begin{array}{l}\text { Std. } \\
\text { Deviation }\end{array}$ \\
\hline A22: & $\begin{array}{l}\text { Achieving performance based on the satisfaction of } \\
\text { patients and community }\end{array}$ & & 21 & 4.13 & .743 \\
\hline A23: & $\begin{array}{l}\text { Citizen Participation in decision making and } \\
\text { upholding public trust }\end{array}$ & & 21 & 3.36 & .929 \\
\hline A24: & $\begin{array}{l}\text { Keeping in mind the expectation of elected authority } \\
\text { (MCA, MPs, Senators, Governors, Presidents }\end{array}$ & & 21 & 3.93 & .799 \\
\hline A25: & $\begin{array}{l}\text { Implementing collective will of community } \\
\text { members in relation to health service delivery }\end{array}$ & & 21 & 4.47 & .743 \\
\hline A26: & $\begin{array}{l}\text { Working with advocacy groups civil society in } \\
\text { improving health services }\end{array}$ & & 21 & 3.73 & .961 \\
\hline A27: & $\begin{array}{l}\text { Working with other state agencies in improving } \\
\text { health services }\end{array}$ & & 21 & 4.20 & .561 \\
\hline A28: & $\begin{array}{l}\text { Maintaining a good relationship with the public and } \\
\text { media }\end{array}$ & 21 & & 4.29 & .469 \\
\hline
\end{tabular}

Focusing on expectation of elected officials $(\overline{\mathrm{x}}=3.93)$ followed next by working with advocacy groups civil society in improving health services $(\bar{x}=3.73)$ and finally citizen participation in decision making and upholding public trust $(\overline{\mathrm{x}}=3.36)$.

6.3 Public Accountability Mechanism Accorded Priority by Hospital Administrators in the Health Sector Under Normal Conditions

Analysis of the data to reveal which accountability mechanism is preferred during normal day to day activities of hospital administrators is presented in table 6 below. Results in this table presents computed means of account rendering activities associated with each of the four accountability mechanisms namely: hierarchical, legal, professional and political. Analysis suggest that professional accountability accorded priority $(\overline{\mathrm{x}}=4.42)$ followed by hierarchical accountability $(\overline{\mathrm{x}}=4.36)$ then by legal accountability $(\overline{\mathrm{x}}=4.26)$ and lastly political accountability $(\bar{x}=4.02)$. 
Table 6. Presentation of result for accountability under normal conditions

\begin{tabular}{|llll|}
\hline Accountability Mechanism & N & Mean & Std. Deviation \\
\hline Hierarchical Accountability & 21 & 4.36 & 0.713 \\
Legal Accountability & 21 & 4.26 & 0.726 \\
Professional Accountability & 21 & 4.42 & 0.724 \\
Political Accountability & 21 & 4.02 & 0.744 \\
\hline
\end{tabular}

\subsection{Accountability Mechanism Accorded Priority in Instances of Crisis}

Participants in the survey were asked to rate which source of accountability they would prioritize in case a serious challenge/problem in the hospital is widely reported in the media, captures the attention of the nation or county and everyone is enquiring about the matter and there is a multi-agency probe. This question was designed to measure which among the four mechanisms of accountability mechanism is given priority in times of crisis. Table 7 below presents analysed responses from the 21 respondents who participated in the survey

Table 7. Accountability mechanism accorded priority in instances of crisis

\begin{tabular}{|l|l|}
\hline Accountability Activities in Aftermath of Crisis & $\%$ of responses \\
\hline Reports to county and national health officials & $71.4 \%$ \\
\hline Enquiry by the hospital board & $64.3 \%$ \\
\hline Probe by professional boards & $42.9 \%$ \\
\hline Engaging the media to respond or to clarify matters & $28.6 \%$ \\
\hline Probe by Commissions such as EACC, CAJ, KNHRC & $21.4 \%$ \\
\hline Response to public protests & $21.4 \%$ \\
\hline Initiation of legal process & $14.3 \%$ \\
\hline Probe by County Assembly/National Assembly /Senate & $14.3 \%$ \\
\hline Questioning from the Cabinet Secretary & $14.3 \%$ \\
\hline Audit by the Kenya National Audit Office & $14.3 \%$ \\
\hline Probe by Police & $7.1 \%$ \\
\hline Questioning by the area MP & $7.1 \%$ \\
\hline Questioning by the relevant Governor & $7.1 \%$ \\
\hline
\end{tabular}

Hospital administrators in the health sector were asked what accountability activity is mostly applied in the aftermath of a crisis in their hospitals. Reporting crisis in the aftermath of a crisis to bosses in the hierarchical structure ranked high at $71.4 \%$ followed by enquiry by hospital boards at $64.3 \%$. Probe by professional boards came third with $42.9 \%$. Media engaging followed at $28.6 \%$ followed by response to probe by relevant commissions and response to public protests which tied at $21.4 \%$. Initiation of a legal process, probe by legislature, cabinet secretary and Kenya National Audit followed with a tie at $14.3 \%$. Probe by police and questions from the area MP and the Governor came last with a tie at $7.1 \%$.

\section{Discussion}

This study focused on the competing accountability and the resultant preferred accountability 
mechanism under normal conditions. The study expected public administrators in the health sector to prefer hierarchical accountability over the other mechanisms of accountability namely legal, professional and political. This expectation is based on the assumption that the public health sector and by extension, the public sector is ordered based on the Weber's Ideal-Type bureaucracy where duties are fixed, positions are arranged hierarchically, and where a system of rules dominates operations. However contrary to our expectations, our data showed that professional accountability $(\overline{\mathrm{x}}=4.42)$ seem to be given precedence over hierarchical accountability ( $\overline{\mathrm{x}}=4.36)$, legal accountability $(\overline{\mathrm{x}}=4.26)$ and political accountability $(\bar{x}=4.02)$ mechanisms of public accountability in normal conditions. This revelation supports the classical argument by Friedrich (1940) that professional accountability was the single most effective tool to guarantee public accountability because (hospital) administrators possess specialized knowledge lacking among the general citizenry. Health administrators, in their career in the management of hospital are professional in a more technical sense.

Additionally, Friedrich (1940) argued that professional accountability has been necessitated by the need for discretion due to the enlargement of the public sector, specialization and also as a result of increasing "government problems". Friedrich seemed to share similar views with Weber's Ideal-Type Bureaucracy. With the enlarged government, Weber foresaw the importance of professional accountability and viewed it as an outcome of a more rational bureaucracy where control would be "exercised on the basis of technical expertise" (Tomkins, 2005, p.43). This arrangement is propagated through selection and promotion of administrators based on their competence to perform specific or specialized duties. The health sector in Kenya is ordered in Weberian Ideal-type Bureaucracy.

In an attempt to explain why professional accountability is the most common form of public accountability, Boven (2007) argued that this mechanism is an individualized kind of accountability. Using the tag "each for himself" he asserted that individual accountability occurs when "each individual official is held proportionately liable for his (her) personal contribution to the infamous conduct of the organization" (p.459). Therefore, based on the findings this study makes an interpretation that individual administrators pay attention to professional accountability because each individual is judged on the basis of individual contribution as opposed holding to accountable the entire organization collectively. The administrators through their induction and experience are aware of the implication of personal liability in the public sector arising from their acts of omission or commission. They are also cautious of the implication of such acts as professional negligence and the damaging effect it can have on one's career and standing in the society. Consequences of acts contravening professional accountability include; dismissal, surcharging and even prosecution (Public Service Code of Regulation, 2006).

The superiority of professional accountability can also be traced and viewed from the historical context and from public sector reform perspectives. The modern public services across the world and in Kenya have experienced reforms from the old bureaucratic public service to New Public Management that has embraced private sectors entrepreneurial ideals. According to Lægreid (2014), the New Public Management is "about hands-on professional 
management, explicit standards of performance, a greater emphasis on output control, and private-sector management techniques" (p.2). At the heart of emphasis on output of performance is a well trained professional who is able to utilize expertise and resources to deliver public services (Table 4, code A.18, $\bar{x}=4.47$ ). This ideal of appropriate use of public resources was ranked equally as compliance with professional norms.

Several other studies support this conclusion on preference for professional accountability in other jurisdictions. Among them, Byrkjeflot (2013) singled out professional accountability as the dominant accountability over political accountability, a traditional source in his analysis of NPM reforms in the hospital context in Norway. Similar conclusions were reached by Romzek and Dubnick (1987) where a space shuttle accident was attributed to disregard for professional accountability.

The next and final section of our study concentrated on the consequences of a crisis from an accountability perspective. Of particular interest to this study were observations by Schwartz and Sulitzeanu-Kenan (2004) that "It seems quite reasonable to expect shifts in administrative values in response to crisis or disaster situations."(p. 80). In agreement with this perspective, this study expected a shift from hierarchical to legal accountability as a mechanism that is accorded more priority than the other mechanisms of accountability by public administrators in the health sector in Kenya in crisis situations. Some of the activities that trigger crisis situation boarders on whether a law or certain regulation have been broken or not, thus the thoughts about legal accountability as a mechanism prioritized by administrators during crisis However, contrary to this position, the study findings revealed that hospital administrators leaned towards hierarchical accountability. In the aftermath of a crisis 71.4 and 64.3 per cent of the hospital administrators would focus on providing accounts and reports to county and national ministry of health executives and the hospital boards respectively (table 7). These two channels of reporting represent hierarchical accountability. No other source of accountability achieved more that 50 per cent response rate in the event of a crisis.

Preference of hierarchical over the other three mechanisms of accountability during crises is affirmed by Romzek and Ingraham (2000) where they concluded that "We find that while institutional rhetoric and managerial conditions encouraged entrepreneurial behavior and initiative, the administrative reality still emphasized a risk-averse, rules-oriented approach to accountability when things went wrong" (p.250).

Similarly from the Kenya's health sector context, the hospital administrators are encouraged to step out of compliance based accountability mindset to adopt innovations, entrepreneurial spirit that focuses on performance based accountability in service delivery. This has been encouraged during induction, in the annual performance contraction sessions and in various leadership development courses. However during disasters such as preventable maternal and newborn deaths, the hierarchical mechanisms that include death audit (performed by ad hoc inter professional team) to check on compliance with protocols, rules and guidelines are involved as first activity among a chain of activities including questioning from the authority in the chain of command. The ultimate responsible persons in the chain of command include the executive for health at the county level and the cabinet secretary for health at the national 
level. In the Kenyan governance model, ministers take personal responsibility for the actions of their juniors in the ministries they head. This is close to Westminster model of ministerial responsibility pointed out by Mulgan (1997). In this form of hierarchical accountability, the administrators may also receive senior teams from both the county and national government who normally conduct fact finding mission in order to design appropriate measures such as accurate media briefing and remedial administrative measures. Alternatively, such teams request for reports of the occurrence to be sent to them urgently.

Apart from Romzek and Ingraham (2000) several scholars on public accountability in the aftermath of crisis reached similar conclusion on the importance of hierarchical accountability. For example Jin and Song (2015) in the assessment of accountability after the 2014 ferry disaster in South Korea, singled out incidences where the lower ranking officials looked upon those higher up in the bureaucracy for orders and that no lower ranking official took decision at the accident scene. In the aftermath of Japan's nuclear disaster in Fukushima, Kim (2017) demonstrated that hierarchical accountability and ultimately political accountability are important than professional accountability.

\section{Conclusion}

Hospital administrators in Kenya just like in many jurisdictions are confronted by all the four mechanisms of accountability namely hierarchical, professional, legal and political. The intensity of the four mechanisms in ensuring accountability varies. Hence competing mechanisms of public accountability is valid model of analysing accountability in the health sector in Kenya. The study has demonstrated that hospital administrators play a crucial role in contributing to accountability in the hospitals (public agencies). The existence of diverse mechanism of holding public administrators accountable is a testimony of the growing influence of accountability a value in public sectors. Enhanced accountability is a key objective of public sector reforms, decentralization of health services and anti-corruption campaign in the public sector in Kenya.

This study proposes further research in public accountability in health sector in Kenya. Future research should focus on the effect of multiple and competing accountability on variables such as performance, and on actual disasters. Other areas that might be considered include effectiveness of professional accountability probes such as medical board hearings. This study suggests further research using a larger sample size to draw conclusions in exploring the challenge of multiple accountability from a national perspective.

In the realm of policy, Van Belle \& Mayhew (2016) observed that accountability is now generally acknowledged in the fields of health policy, health systems and global health. From policy perspective the study makes the following recommendations. The study observed that among areas of accountability especially hierarchical accountability, there are shared function between counties and the national government. However the pursuit of accountability by the latter is weakened by the lengthy process introduced by the County Government Act, 2012. The national government has to pass through the Council of Governors, an extra constitutional umbrella body for the 47 county governments for any issue arising from within the county governments. This process is lengthy and may water down the pursuit of 
accountability by the national government. There is a need to review the Act to address this concern. This study proposes where necessary and in incidences of higher magnitude such as during crisis situations the national government ought to intervene directly.

Under political accountability, the drivers of accountability especially during crisis include the media, the national and county legislative assemblies and politician operating outside the legislature. The community and patients are not given serious audience in political accountability as observed by Kweit \& Kweit (2004). Patients, their relatives and the community ought to be given more say in holding hospital administrators accountable as envisaged under Chapter 4 on the Bill of Rights in the Constitution and in the County Governments Act, Article 87 on principles of citizen participation in counties affairs including hospital management.

\section{References}

Aberbach, J. D., \& Rockman, B. A. (2000). In the Web of Politics: Three Decades of the U.S. Federal Executive. Washington, DC: The Brookings Press

Atela, M. H. (2013). Health system accountability and primary health care delivery in rural Kenya: An analysis of the structures, process, and outcomes. (doctoral thesis). https://doi.org/10.17863/CAM.16253

Baruch, Y. (1999). Response rate in academic studies: A comparative analysis. Human Relations, 52(4), 421-438. https://doi:10.1177/001872679905200401

Bennett, A. (2004). Case Study Methods: Design, Use, and Comparative Advantages. In Y. Nahmias-Wolinsky (Ed), Models, Numbers, and Cases (pp. 19-55) Ann Arbor, MI: University of Michigan Press

Blind, P. K. (2011). Accountability in Public Service Delivery: A Multidisciplinary Review of the Concept. A paper for the Expert Group Meeting Engaging Citizens to Enhance Public Sector Accountability and Prevent Corruption in the Delivery of Public Services Vienna, Austria, 7-8 and 11-13 July 2011

Boven, M. (2007). Analysing and assessing accountability: A conceptual framework. European Law Journal, 13(4), 447-468. https://doi: 10.1111/j.1468-0386.2007.00378.x

Boven, M., \& Schillemans, T. (2011). The challenge of multiple accountabililty. Does redundancy lead to overload. In M.J Dubnick \& H.G. Frederickson, (Eds.), Accountable governance: problems and promises. (pp. 3-21), Armonk, NY: M.E. Sharpe.

Boven, M., Goodin, R., \& Schillemans, T. (2014). Public Accountability. Oxford: Oxford University Press

Brinkerhoff, D. (2003). Accountability and Health Systems: Overview, Framework, and Strategies. Bethesda, MD: The Partners for Health Reformplus Project, Abt Associates, Inc

Butler, J. (2010). Evolving Political Accountability in Kenya. Center for African Studies. Urbana-Champaign: University of Illinois 


\section{Macrothink}

Journal of Public Administration and Governance ISSN 2161-7104 2020, Vol. 10, No. 2

Byrkjeflot, H. (2013). Hospital reforms: Consequences for accountability regimes in Denmark, Germany and Norway. DRAFT paper prepared for 22nd IPSA World Congress Madrid July 8-12, 2012 Thursday, July 12, 13:00-14:45

Cendón, A. B. (1999). Accountability and public administration: Concepts, dimensions, developments, openness and transparency in governance: Challenges and opportunities.https://unpan1.un.org/intradoc/groups/public/documents/.../unpan006506.pdf

Cornwall, A., Lucas, H., \& Pasteur, K. (2000). Introduction: Accountability through Participation: Developing workable partnership models in the health sector. IDS Bulletin, 31(1), 1-13. https://doi: 10.1111/j.1759-5436.2000.mp31001001.x

Denhardt, R., \& Denhardt, J. (2007). The new public service: Serving rather than steering. New York, NY: M.E. Sharpe, Inc.

Dimock, M. E., \& Dimock, G. O. (1969). Public administration (4th ed). Hinsdale, IL: Dryden Press.

Dowdle, M. D. (2006). Public accountability: Designs, dilemmas and experiences. Cambridge: Cambridge University Press.

Dubnick M. J., \& Yang, K. (2011). The pursuit of accountability: Promise, problems, and prospects. In D. Menzel \& H. White (Eds.), The State of public administration (pp. 171-86). Armonk, NY: M. E. Sharpe, Inc.

Etikan, I., Musa, S. A., Alkassim, R. S. (2016) Comparison of Convenience Sampling and Purposive Sampling. American Journal of Theoretical and Applied Statistics, 5(1), 1-4. https://doi:10.11648/j.ajtas.20160501.11

Finer, H. (1941). Administrative responsibility and democratic government. Public Administration Review, 1(4), 335-50. https://doi: 10.2307/972907

Frederickson, G., \& Smith, K. B. (2003). The Public Administration Theory Primer. Boulder, CO: Westview Press

Friedrich, C. J. (1940). Public Policy and the Nature of Administrative Responsibility. Public Policy, 9(1), 1-20.

Friis-Hansen, E., \& Ravnkilde, C. M. (2013). Social accountability and public service delivery in rural Africa. Copenhagen: Danish Institute for International Studies, DIIS.

Gachie, M., \& Iravo, M. (2016). Determinants of health care service delivery as a devolved function in level four hospitals in Kiambu County, Kenya. Strategic Journal of Business Change, 3(12), 219-239.

Gailmard, S. (2012). Accountability and Principal-Agent Models. In M. Bovens, R.E. Goodin, \& T. Schillemans (Eds.), Oxford Handbook of Public Accountability. (pp. 34-52) Oxford: Oxford University Press. https:// doi: 10.1093/9780199641253.013.0016

Gicheru, J. E. (2007). Independence of the Judiciary: Accountability and Contempt of Court. 
Nairobi: Kenya Law 2007. https://doi: 10.1093/oxfordhb/9780199641253.013.0016

Jarvis, M. D. (2014). Hierarchy. In M. Bovens, R.E. Goodin, \& T. Schillemans (Eds.), Oxford Handbook of Public Accountability. (pp. 78-92) Oxford: Oxford University Press. https://doi: 10.1093 /9780199641253.013.0016

Jin, J., \& Song, G. (2015). Bureaucratic accountability and disaster response: Why did the Korea Coast Guard fail in its rescue mission during the Sewol ferry accident?, Risk, Hazard \& Crisis in Public Policy, 8(3), 2017, 220-243. https://doi: 10.1002/rhc3.12115

Johnston, J. M., \& Romzek, B. S. (1999). Contracting and accountability in state medicaid reform: Rhetoric, theories, and reality. Public Administration Review, 59(5), 383-399.

Jos, P. H., \& Tompkins, M. E. (2004). The accountability paradox in an age of reinvention: The perennial problem of preserving character and judgement. Administration \& Society, 36(3), 255-28. https://doi:10.1177/0095399704263479

Kameri-Mbote, P., \& Akech, M. (2011). Kenya: Justice Sector and the Rule of Law. Nairobi: Open Society Foundations.

Kenya Anti- Corruption Commission. (2010). Sectoral perspective on corruption: The case of Kenya public health service delivery. Kenya Anti Corruption Commission.

Kettl, D. F. (2002). The Transformation of Governance: Globalization, Devolution, and the Role of Government. Public Admistration Review, 60(6), 488-497 https://doi.org/10.1111/0033-3352.00112

Kim, S. E., \& Lee, J. W. (2010). Impact of competing accountability requirements on perceived work performance. The American Review of Public Administration, 40(1), 100-118. https://doi:10.1177/0275074008329469

Kim, Y. (2017). Analyzing accountability relationships in a crisis: Lessons from the Fukushima disaster. American Review of Public Administration, 00(0), 1-18. https:// doi: $10.1177 / 0275074017724224$

Kimiru, P. M. (2008). The role of professional counseling associations in professional counseling practice in Kenya. (Unpublished Masters Thesis). University of Nairobi.

Kuipers, S., \& Hart, P. (2014). Crisis management: Coping with the intolerable. In M. Bovens, R.E. Goodin, \& T. Schillemans (Eds.), Oxford Handbook of Public Accountability. Oxford: Oxford University Press. (pp. 589-602).

Lægreid, P. (2014). Accountability and New Public Management. In M. Bovens, R. E. Goodin, \& T. Schillemans (Eds.), Oxford Handbook of Public Accountability. (pp. 241-259) Oxford: Oxford University Press. https://doi:10.1093/oxfordhb/ 9780199641253.013.0008

Maass, A. A., \& Radaway, L. I. (1959). Gauging administrative responsibility. In C. Stivers (Ed.), Democracy, bureaucracy, and the study of administration, (pp.163-81). Boulder, CO: Westview Press. 
Machira, Y. W., \& Nizam, R. (2015). Integrating social accountability in healthcare delivery: lessons drawn from Kenya. Kenya devolution; no. 4. Washington, D.C.: World Bank Group.

McDanel, P. (2012). Review of "Accountable Governance: Problems and Promises". Journal of Public Affairs Education, 18(3), 611-613. Retrieved May 9, 2020, from www.jstor.org/stable/23272658

Minja, D. (2013) Accountability practice in Kenya's public service: lessons to guide service improvement. International Journal of Business and Management Review, 1(4), 54-63

Mulgan, R. (1997). The Processes of public accountability. Australian Journal of Public Administration, 56(1), 25-36. https://doi.org/10.1111/j.1467-8500.1997.tb01238.x

Mulgan, R. (2003). Holding Power to Account: Accountability in modern democracies. London: Palgrave

Ndege, P. O. (2009). Colonialism and its legacies in Kenya. Lecture delivered during Fulbright- Hays Group project abroad program: July 5th -August 6th 2009 at the Moi University, Main Campus.

Nulty, D. D. (2008). The adequacy of response rates to online and paper surveys: what can be done? Assessment \& Evaluation in Higher Education, 33(3), 301-314. https://doi.org/10.1080/02602930701293231

Nyamu, H. (1975). The state of civil service today. Nairobi. Government Printers

Odhiambo-Mbai, C. (2003). Public service accountability and governance in kenya since independence. African Journal of Political Science, 8(1), 113-145.

Odhiambo-Mbai, C., \& Wanyande, P. (2001). Public service ethics in Kenya in United Nation (2001). Public service ethics in Africa, 2, New York, NY: United Nations.

Republic of Kenya (2006). Code of Regulation. Nairobi: Public Service Commission Retrieved from http://www.eacc.go.ke/default.asp?pageid=21

Romzek, B. S., \& Ingraham, P. W. (2000). Cross pressures of accountability: initiative, command, and failure in the Ron Brown plane crash. Public Administration Review, 60(3), 240-253. https://doi.org/10.1111/0033-3352.00084

Romzek, B., \& Dubnick, M. (1987). Accountability in the public sector: Lessons from the Challenger tragedy. Public Administration Review, 47(3), 227-238. https:// doi:10.2307/975901

Romzek, B. S. (2000). Dynamics of Public Sector Accountability in an Era of Reform. International Review of Administrative Sciences, 66(1), 21-44. https://doi.org/10.1177/0020852300661004

Salminen, A., \& Lehto, K. (2012). Accountable to whom? Exploring the challenge of multiple accountabilities in Finnish public administration. Halduskultuur-Administrative Culture, 13(2), 147-162. 


\section{Macrothink}

Journal of Public Administration and Governance ISSN 2161-7104 2020, Vol. 10, No. 2

Schillemans, T., \& Busuioc, M. (2014). Predicting public sector accountability: From agency drift to forum drift. Journal of Public Administration Research and Theory, 24(1), 1- 25 https://.doi:10.1093/jopart/muu024

Schwartz, R., \&Sulitzeanu-Kenan, R. (2004). Managerial values and accountability pressures: Challenges of crisis and disaster. Journal of Public Administration Research and Theory, 14(1), 79-102. https://doi.org/10.1093/jopart/muh005

Sihanya, B. (2012). The role of the Judiciary in the accountability and governance of the devolved Government structure. A Presentation to the Institute of Certified Public Accountants of Kenya (ICPAK) 20th Economic Symposium at the Hilton Hotel, Nairobi, February 24, 2012.

Tello, J., \& Baez-Camargo, C. (2015). Strengthening health system accountability: A WHO European Region multi-country study. Copenhagen: WHO Regional Office for Europe.

Tettey, W. J. (2006). The Politics of Media Accountability in Africa: An Examination of Mechanisms and Institutions. International Communication Gazette, 68(3), 229-248. https://doi.org/10.1177/1748048506063763

Tompkins, J. R. (2005). Organization Theory and Public Management. Belmont, CA:Thomson Wadsworth

Transparency International (2006). Transparency International Global Corruption Report 2006: Corruption in The Health Sector: Seeking the Cure. Report presented on February 1, 2006 at the University Club of Washington, D.C. University Hall, Second Floor 1135 16th Street, Northwest Washington, D.C.

Van Belle, S., \& Mayhew S. H. (2016). What can we learn on public accountability from non-health disciplines: a meta-narrative review. BMJ Open, 6(7). https://doi:10.1136/bmjopen-2015- 010425

Waterman, R. W., \& Meier, K. J. (1998). Principal-Agent Models: An expansion? Journal of Public Administration Research and Theory, 8(2), 173-202. https://doi.org/10.1093/oxfordjournals.jpart.a024377

Yin, R. (1994). Case study research: Design and methods (2nd ed.). Beverly Hills, CA: Sage Publishing.

\section{Copyright Disclaimer}

Copyright for this article is retained by the author(s), with first publication rights granted to the journal.

This is an open-access article distributed under the terms and conditions of the Creative Commons Attribution license (http://creativecommons.org/licenses/by/4.0/). 